\title{
Vocational English Training for “Go Clean” Partners
}

\author{
Clara Herlina ${ }^{1}$ \\ ${ }^{1}$ English Department, Bina Nusantara University, Jakarta 11480, Indonesia \\ Email: claraherlina@yahoo.com
}

\begin{abstract}
Nowadays, almost all people living in Jakarta use application for everyday needs, from transportation, buy food until cleaning houses. One of the companies that provide those services through online application is GOJEK. GOJEK offered a lot of services, such as GO Ride, GO Food, GO Massage and Go Clean. Go Clean is particularly giving service for cleaning houses or apartments and it has a lot of customers. Unfortunately, Go Clean partners often have to decline customers, particularly foreigners, because they are not able to converse in English. Thus, this community program is created to give training to Go Clean partners so that they will be able to conduct a simple conversation in English with foreign customers. The materials include introduction, parts of the house and price negotiation. After the training, it is expected that the workers will gain more customers and eventually it will increase their income.
\end{abstract}

Keywords: Go Clean, English conversation, house cleaning, vocational

\section{Introduction}

English for special purpose (ESP) can be given to university students or people who are already working. The focus of ESP is particular vocabulary and skills that people need in their job (Hutchinson \& Francisco, 1987). Since its focus is on occupation or profession, a course in ESP will be specified such as English for Technical workers, English for medical practitioners, etc.

ESP can also be given to house cleaners, as house cleaner is one of the most needed occupations. Nowadays, people in Jakarta or in big cities often rely on outbound house cleaners rather than home stay maids to clean their houses. Home cleaning service can be obtained from an online application called GoClean from GOJEK company. The workers who give the cleaning service are called GoClean partners. Since it is online based, GoClean partners can take orders from everybody who has Gojek account. Sometimes, GoClean partners refuse to take orders from certain customers because of language problem. They are not able or are not willing to communicate in English with foreign customers because they are not confident enough to speak in English. As a result, many of their orders were cancelled because of this problem.

Therefore, in this community development program, we give English training for GoClean partners to enable them to understand work (house cleaning) related vocabulary and to conduct simple conversation in English with the prospective English-speaking customers.

\section{Go Clean}

Go Clean is one of the services provided by Gojek company. Go Clean gives the services of home cleaning, from bedroom, living room, kitchen, bathroom and dining room. Moreover, Go Clean partners can also clean house furniture such as cabinet, refrigerator, stoves, dishes even do the ironing. According 
to its website: www. gojek.com/goclean, Go Clean is the only solution for home cleaning for three reasons:

- On-demand service: Go Clean can be of service anytime so customers can do more important things.

- Professionally trained cleaners: their partners are professional and well-trained.

- Trusted: every GoClean partner works based on SOP and are under GoLife supervision

Moreover, GoLife services provide three kinds of guarantee for their services

- Rework guarantee: GoLife gives a rework guarantee under applicable provision

- Service insurance: GoLife offers insurance for items which are lost during service, physical injury caused by the partner and medical treatment for such injury without incurring extra charges.

- Trained partners: their partners have passed background checks, skills training, and work procedure provision. Vocabulary for house cleaner

Vocabulary and simple conversation for house cleaners

According to Tenieshvili, 2019, there are two layers of ESP course. The first layer covers all common knowledge in the specific field of study. The second layer focuses on the details of an individual's specialization.

Thus, in this training, the participants are taught the general vocabulary that relate to the parts of a house, verbs related to cleaning a house, and unit of currency. After that, the participants are taught simple conversation related to their work, in particular as GoClean partner.

The vocabularies given are meant to be used as productive vocabulary. Brysbaert et al. (2016) defines productive vocabulary as "words that can be produced within an appropriate contexts and match the intended meaning of the speaker or signer". Since the partners need to use those vocabularies in their works, to they have to understand, memorize and practice using the vocabularies. The vocabulary given to them are limited and practical ones in the hope that those words can become their productive vocabulary. Some samples of house related vocabulary are: living room, bedroom, kitchen, bathroom, terrace, mopping, ironing, sweeping, cooking, washing, and so on. Meanwhile, the conversations given are confirming orders, cancelling orders and giving price.

\section{Method}

Vocational English training for Go Clean partners was given at the head office of GOJEK at Jl. Kemang Selatan 1 D, RT 1/RW 2, Jakarta Selatan. The participants are 25 Go Clean partners. The training program was delivered on 26 July 2016 for the duration of 3 hours, from 11.00 to 14.00. This community development program was organized by English Department Binus University. The program was funded by ComDev Binus University with the amount of Rp. 2.500.000. The materials for this training were provided by English Department Binus University in collaboration with GOJEK head office.

\section{Result and Discussion}

The training materials are divided into several sessions. For each session, the instructor begins with the explanation or lecturing to the whole class. After that, the participants are asked to practice the material given, either in pairs or in groups.

The first session is self-introduction. In this session, the participants are trained to introduce themselves and role play the conversation as if they were contacted by the customers. The phrases used for introducing themselves are:

- Hi, I'm.....

- I'm from Go-Clean and I will clean your house today 
After everyone has practices introducing themselves, the next session is learning the vocabularies related to the parts of the house. Here are the vocabularies that they have to learn.

Table 1 List of vocabulary

Ruangan-ruangan di rumah (Parts of a house)

\begin{tabular}{|l|l|l|}
\hline Parts & English & Indonesian \\
\hline Outside & Yard & Pekarangan rumah \\
\hline & Backyard & Halaman belakang \\
\hline & Basement & Ruang bawah tanah \\
\hline & Garage & Garasi \\
\hline Rooms & Living room & Ruang tamu \\
\hline & Bedroom & Kamar tidur \\
\hline & Bathroom & Kamar mandi \\
\hline & Dining room & Ruang makan \\
\hline & Family room & Ruang keluarga \\
\hline & Kitchen & dapur \\
\hline Furniture/ others & Cupboard & Lemari \\
\hline & Door & Pintu \\
\hline & Window & Jendela \\
\hline & Curtain & Tirai \\
\hline & Window sill & Ambang jendela \\
\hline & Stairs & Tangga \\
\hline & Window pane & Kaca jendela \\
\hline & Wood stove & Tungku kayu \\
\hline
\end{tabular}

Knowing the vocabulary of a house is important for a house cleaner. However, it is not easy to memorize all the words at once. So to facilitate or improve their understanding, we have to go around the training place and name the parts one by one. By touching or identifying the real object, the participants will be able to memorize the English words easier.

Before going to the customers' location, a Go Clean partner has to call the customer first. Why should the customer be called? It is to ensure that the customer confirms the order and does not cancel the order when the partner has already embarked to the customer's house. Thus, the next lesson is the simple conversation for confirming and cancelling order from clients. When the partner has arrived at the client's house, he/she has to confirm their arrival. Here are the phrases used.

\section{Confirming your order}

- Hi, it's Johan from Go Clean. Is it Mr. James? I would like to confirm your order for our service at/in.... I will be there in 30 minutes. Please wait.

\section{Cancelling your order}

- Hi, it's Johan from Go Clean. Is it Mr. James? I'm sorry, I have to cancel the order due to...(high demand, heavy rain, etc.)

\section{Confirming your arrival}

- Hi, it's Johan from Go Clean. I am in front of your house right now. Would you please open the door?

Those sentences are practiced and role played until the participants can say them fluently without looking at their notes. 
When Go Clean partner has arrived at the client's house and is let in by the client, he has to reconfirm the duration of order based on the scope of the works that can be done. Therefore, before beginning the work, the partner should scan the working place and clarify what he can and cannot do. These are the sentences used for this purpose.

\section{If the scope and duration are suitable}

- I have checked the rooms and I will clean it in...hours.

\section{If the scope and duration are not suitable}

- I'm sorry I can't clean this room because :

- We don't do laundry (mencuci), pet grooming (merawat binatang), baby sit (menjaga anak), and vehicle washing (mencuci kendaraan).

- We don't clean attic (loteng), garage (garasi), rooftop (atap), storage room (gudang), swimming pool (kolam renang) and pet house (rumah hewan).

\section{If the duration is not enough}

- Extra time is needed, it's too big/it's dirty

\section{Offering extra service}

- We also have extra service, such as: washing dishes (mencuci piring), ironing and folding clothes (menyetrika dan melipat baju), cleaning stove area (pembersihan area kompor), cleaning fridge (pemberishan kulkas), cleaning cabinet (pembersihan cabinet), cleaning kitchen set (pembersihan kitchen set).

After the partner has done all the works specified by the client, the partners should ask the client to evaluate the results of his/her works. She also has to ask the client if there is something else she should do. The phrase for this purpose is here.

\section{Evaluating the work}

- Please take a look. Let me know if there's anything else that I can do.

The last session is discussing about the payment. There are two methods of payment, cash payment or payment through the application, called Go Pay. Yet for those methods, partners should be able to mention exactly the price in English. The total cost for service is calculated by multiplying the duration of work with the basic fee per hour, so knowledge in basic math in English is also needed. They should know how to multiply, add, or subtract to be able to count the payment and also give the change. The phrases for this purpose are:

\section{Payment}

- How much?

- I have worked for three hours, so the total cost is $3 \mathrm{X} 45.000=135.000$ (three times forty five thousand per hour becomes one hundred thirty five thousands rupiah).

- Here's the change (Ini kembaliannya).

To practice this conversation, the instructor asked the participants to role play using real money. The instructor also helps them with the words for other amounts of money, such as one hundred, one thousand, fifty thousand, etc.

All of the conversations from the first session until the last session are practiced over and over again until all the participants understand and can perform the conversation fluently without looking at the materials given to them. 


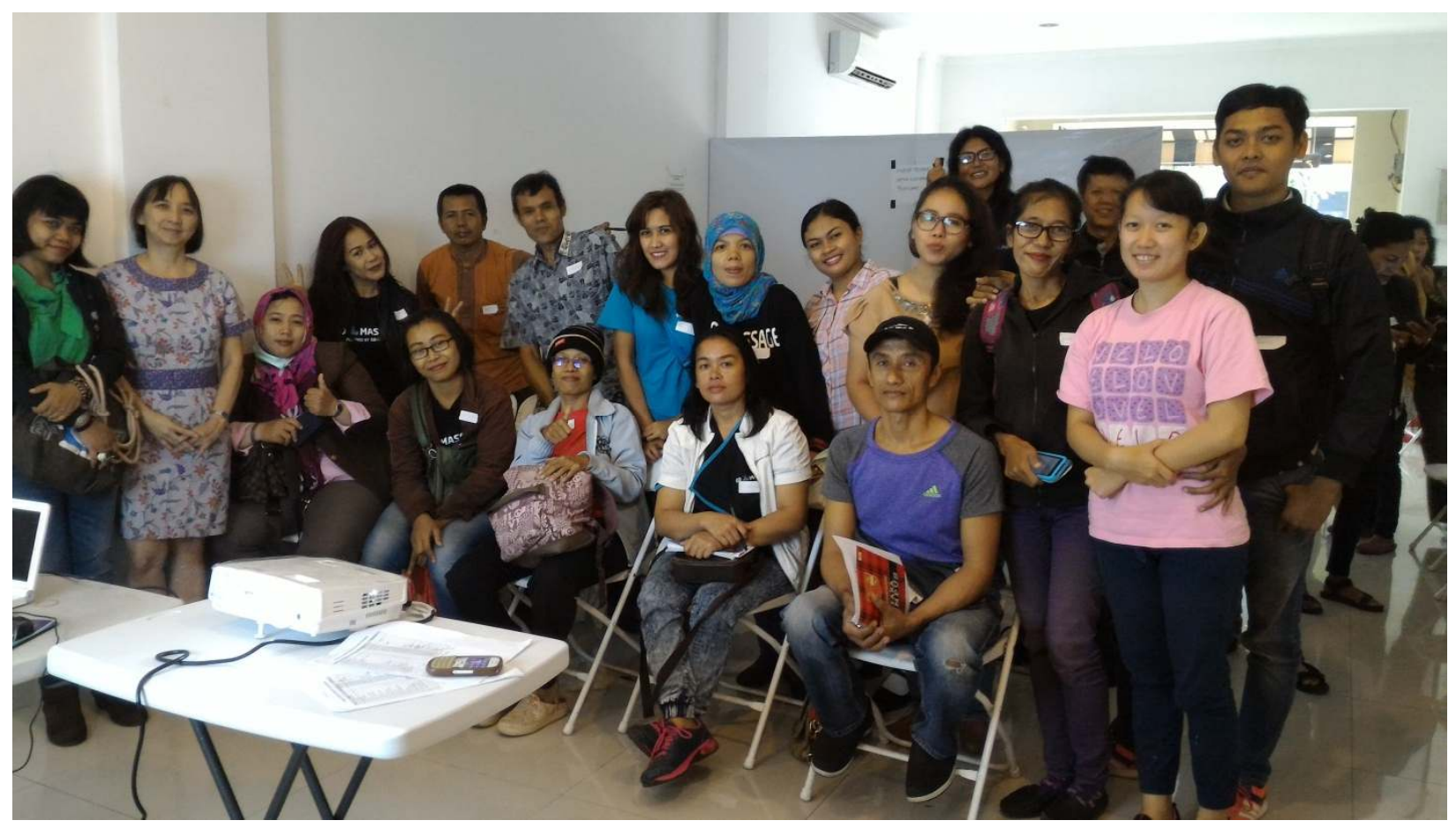

Picture 1. GoClean training participants

\section{Conclusion}

Vocational English training for Go Clean partners is very useful to improve their ability in conversing in simple English. In this training they have learned about the vocabularies needed for house cleaning, and simple conversation for confirming or cancelling order and also discussing payment. By attending this training, Go Clean partners will be able to perform simple conversation in English; thereby they will be able to take orders from foreigner clients. In so doing, their income will increase.

In the future, this program should be continued because English training will empower and open more opportunity for white collar workers to improve their economy.

\section{Reference}

Brysbaert M, Stevens M, Mandera P and Keuleers E (2016) How Many Words Do We Know? Practical Estimates of Vocabulary Size Dependent on Word Definition, the Degree of Language Input and the Participant's Age. Front. Psychol. 7:1116

Hirsh, D.; Nation, I.S.P. (1992). "What vocabulary size is needed to read unsimplified texts for pleasure?" Reading in a Foreign Language. 8 (2): 689-696

Hutchinson, T. \& Francisco, A. (1987) English for Specific Purposes: A learning-centered approach. Cambridge: Cambridge University Press.

Tenieshvili, Anna (April 1, 2019). "Towards Various Aspects of Teaching Language for Specific Purposes at Higher Education Institutions". Journal of Foreign Language Education and Technology: 111126. Retrieved 20 November 2019. 